\title{
PROFILE OF TOURISTS VISITING CULTURAL HERITAGE CITIES: COMPARATIVE STUDY OF SELECTED CITIES IN CENTRAL EUROPE
}

\author{
Mariola Tracz ${ }^{1}$ (D) Małgorzata Bajgier-Kowalska² \\ ${ }^{1}$ Polish Geographical Society, Department of Kraków \\ Podchorażych 2, 30-084 Kraków: Poland \\ e-mail:mtracz-62@o2.pl \\ ${ }^{2}$ Faculty of Law, Administration and International Relations \\ Department of International Tourism and Social Geography \\ Andrzej Frycz Modrzewski Kraków University \\ Gustawa Herlinga-Grudzińskiego 1, 30-705 Kraków: Poland \\ e-mail: malbajkow@interia.pl
}

\begin{abstract}
The aim of this paper is to explore the profile of tourists visiting Budapest, Prague and Warsaw. These cities were selected for their rich cultural heritage and change in volume of tourism in recent years. Survey data $(\mathrm{N}=550)$ and statistical data on tourist volume were used to show similarities and differences in tourist characteristics in terms of socio-demographics and purpose of travel. The study concluded that most tourists visiting these cities are from Western Europe. The main purpose of travel is associated with cultural tourism offerings and entertainment. The study results help understand impact of city tourism development strategies on the tourist profile.
\end{abstract}

\section{Key words}

capital cities - cultural heritage cities - tourist profile - urban tourism - Central and Eastern Europe

\section{Introduction}

Cities play a special role in modern tourism, and capital cities in particular have played a vital role as centers of tourism and transportation. Cities offer visitors a variety of forms of tourism and an exciting climate that differentiates them from other places in the world (Pearce 2001; Ashworth \& Page
2011; UNWTO 2016). Urban tourism is usually defined as various forms of tourism that occur in urban areas and are associated with the tourist attractiveness of cities (Kowalczyk 2003; Edwards et al. 2008). One of these attractions is cultural heritage and associated with them cultural tourism. Contemporary cultural tourism is broadly defined as it relates not just to sites and monuments, but 
to ways of life, creativity, and everyday culture (UNWTO 2017: 18). Modern city tourism often is enhanced by new forms of tourism such as entertainment tourism, business tourism, health tourism, and convention tourism (von Rohscheidt 2016). Cities with exceptional cultural heritage assets, especially those found on the UNESCO World Heritage List, and with well-developed culture-related and entertainment facilities have become popular travel destinations (Trew \& Cockerell 2002; Dunne et al. 2010).

Central and Eastern Europe (CEE) has become a popular tourist destination since the 1990s. The tourism potential of CEE countries is significant. This is evidenced by the large number of national parks, natural and cultural UNESCO heritage sites, and accommodation capacity (Marak \& Wyszkowski 2012). According to statistical data, foreign tourists visiting CEE constituted only $1.24 \%$ of the global tourist volume in 1989, while in 2017 it was 10\% (133.7 mln) (UNWTO 2018a). Growth in tourism volume in CEE countries can be measured via the share of foreign versus domestic tourists, expansion of tourist facilities and results of national tourism policies (Čuka et al. 2015; Banaszkiewicz et al. 2017).

The Czech Republic, Hungary and Poland yield a lion's share of tourist traffic in this region. These countries have a similar history associated with rule by the Hapsburg Empire in the 19th century and the predominance of communism between 1945-1989. Tourist influx to these countries increased rapidly after they joined the European Union (2004) and the Schengen passport-free zone (2007). Tourist volume, especially driven by some EU countries, has grown significantly (Halle \& Page 2006; Ibrahimova 2012; UNWTO 2018b). One of the factors affecting this market is the strengthened Euro/USD against national currency, both increasing some CEE countries' affordability as tourism destinations. These countries' employment level associated with tourism remains around 4\% to 5\% (Statistical Yearbooks - CZSO 2018a, HCSO 2018, SP 2018). In 2017 revenues from tourism were as follows: Czech Republic,
7.8\% of GDP (6.9 bln USD), Hungary $8.2 \%$ (12.3 bln USD), Poland 6\% (12.8 bln USD) (UNWTO 2018a).

The attractions for international tourists are the capitals of these countries due to their multifunctional character. Budapest, Prague, and Warsaw are important centers of both domestic and foreign tourism, providing a diverse offering of urban tourism and cultural tourism. These capitals attract tourists with unique cultural heritage sites, cultural differences, architecture, museums, and various events (Widawski \& Wyszkowski 2012; Dumbrovská \& Fialová 2014). The UNESCO listing of Warsaw (1980), Budapest (1987), and Prague (1992) on the World Heritage List effected an increase in the number of cultural and urban tourists. Tourism has a long tradition in each of these cities. Since the 1990s tourism has stood as a key element of each city's economy.

The purpose of the paper is to explore both the domestic and foreign tourist profile for selected cities in CEE. The cities analyzed in the paper are Budapest, Prague, and Warsaw, as examples of capital cities in the region and major hubs of foreign tourist activity.

\section{Literature review}

Urban tourism is one of the most important forms of tourism both in terms of volume and economic impact. Capital cities and global financial centers have noted enormous growth, notably in cultural tourism and business-oriented travel (Ashworth \& Page 2011; Maitland 2012). Statistical data show urban tourism has a large market share in France, Germany, Great Britain, and also in Central European countries (European Cities... 2017; UNWTO 2018a). The most popular destinations, as measured by high accommodation capacity and number of overnight stays are London, Paris, Rome, Vienna, Berlin, and Barcelona (UNWTO 2018a). In Central Europe, the Czech Republic, Hungary, Poland, and Slovakia have noted an increase in urban tourism. In these countries, urban tourism has contributed to the development of the 
tourism sector as a whole (Aguayo 2005; Hall \& Page 2006; Vagner 2007). This is especially true of capital cities (Budapest, Prague, Warsaw, Bratislava), which have become attractions for international tourists due to their unique cultural and architectural traditions and prestigious hotel chains (Michalko 2001; Widawski \& Wyszkowski 2012).

Growth of air transportation and IT has contributed to continually growing interest in urban tourism and cultural tourism. The spatial conditions of cultural tourism are strongly related to the attractiveness of cities and their geographic location. It is estimated that short-duration travel (called a citybreak, which lasts a maximum of two days), accounts for $38 \%$ of all international trips completed by Europeans (European Cities... 2017). On the other hand, it was estimated that cultural tourism accounts for over 39\% of all international tourist arrivals (UNWTO... 2018b). Other leading factors that now attract tourists to cities including capital cities are sporting and cultural events, shopping centers, recreational centers, famous restaurants, and cafes (Maitland 2012; von Rohscheidt 2016; Harrison \& Sharpley 2017; Zduniak 2017).

Rapid growth of tourism in urban areas, including city breaks, lead to tourist overcrowding. Tensions caused by mass tourism are noted in some European cities such as Barcelona, Venice and Amsterdam (Colomb \& Novy 2017; Milano 2017). Tourism in both Prague and Budapest has increased in recent years with the influx of low-cost airline tourists and the growing brand image of the two cities as a location for cheap entertainment and parties. There has also been rapid growth in the availability of Airbnb accommodations (Ibrahimova 2012; PinkeSziva et al. 2019). Tourism has brought economic benefits for Prague, Budapest and also Warsaw. On other hand, rapidly increasing tourism volumes also bring problems. One is a high tourist concentration in the historical city center, making certain areas virtually offlimits to locals (Dumbrovská \& Fialová 2018; Pinke-Sziva et al. 2019).
The impact of globalization on urban tourism has generated variable results. One of these is a change in the socio-demographic profile of tourists and another is a change in the purpose of travel. Groups of young people now tend to vacation or spend weekends or go on school trips abroad. The number of senior travelers has also increased systematically. All of these new travel patterns extend the tourist season (Edwards et al. 2008).

The travel motives of visitors are related to the aspects of the city that attract them and also to tourist activities. Many studies have shown that tourism nodes can be focused around iconic attractions, shopping, and business precincts or hotels (Kowalczyk 2003; Richards 2018). The number of tourists interested in large-scale events such as concerts, festivals, arts exhibitions, scientific conferences, and sports competitions keeps increasing (Reisinger 2012; Bellini \& Pasquinelli 2016). Some studies find also an increase in the general level of education and the pursuit of new attractions and cultural interactions (Nyaupane \& Andereck 2014). Tourists visiting capital cities and heritage cities declare often an interest in architecture, cultural heritage, and wish to participate in artistic and cultural events (Ashworth \& Page 2011; Poria et al. 2013). Another factor that leads some tourists to visit cities is the "explosion" of business tourism in all its forms: individual business trips, conferences, conventions.

The importance of the tourism market in the development of urban tourism has created a need for data on tourists visiting cities in terms of their motivations and socio-demographics and perception of the urban landscape. Most comparative studies on tourists are conducted from the perspective of place and activity or groups in terms of satisfaction, motivation, and travel patterns (Nyaupane \& Andereck 2014). Although some studies focus on only one or a few constructs and thus appear to be insufficient to provide a deep understanding of visitors and their choice of destination and what its benefits are (Correia et al. 2013). There exist 
few studies on the tourist profile of visitors in capital cities in CEE. The present study fills a gap in this area in the context of tourists, with a focus on socio-demographics and reasons for travel.

\section{Study area}

Budapest, Prague, and Warsaw are old cities with a wide range of cultural heritage assets and a large part of their old city centers is found on the UNESCO World Heritage List. These three cities have a similar population. (Tab. 1). The studied cities are conveniently located along major international highways and are easily accessible by air. The number of tourists in the analyzed cities has increased in the last year. Prague accounts for close to $80 \%$ of tourists visiting the Czech Republic. Warsaw accounts for $53 \%$ of tourists in Poland, while Budapest stands at 28\%. Today, Prague and Budapest are ranked high among the most popular European cities for tourists. In 2018 the largest number of tourists was noted in Warsaw and Prague (Tab. 1). Data reveal that Prague is the overall leader in the tourism sector in the analyzed cities. Over a short period of time, Prague has transformed from a developing tourist city into one of the most visited cities in the world. Both Prague and Budapest are now overcrowded with tourists.

Tourist traffic is mostly focused in the historical areas of cities and in newly explored parts. In Prague most tourists are concentrated in the Old Town between Waclawskie
Namesti and Hradczany Castle including the stretch with Charles Bridge. New tourist areas in Prague include the Visegrad, Zizkov, and Vinohrady districts. In Warsaw tourist traffic is currently concentrated in the Old City including the Royal Castle as well as the Wilanów and Łazienki districts. The Praga district (old part) is also becoming a popular tourist area. In Budapest the most popular tourist parts are Gelert Hill (castle), the Parliament building, and other historical sites in the Buda and Pest districts including the Jewish district, thermal water baths, and St. Margaret's Island. Congestion and tourist business development are most often observed in the historical parts of these cities at sites that are included on UNESCO's list of world cultural heritage sites. Both cities have a high concentration of hotels in historic centers (Simpson 1999; Dumbrovská \& Fialová 2014; Kovacs et al. 2015).

\section{Methodology}

The goal of the study was to explore and compare the profile of tourists visiting Budapest, Prague, and Warsaw. The objectives of the study were to: (1) identify tourists' sociodemographic profiles, (2) identify the purpose of visits, (3) examine challenges linked with tourism management strategies available for the studied cities and their effects on tourists' profile.

The study is based on a literature and data review and a field survey. Data obtained from local and national statistical offices, reports,

Table 1. Tourist volume for Budapest, Prague, and Warsaw

\begin{tabular}{|c|c|c|c|c|c|c|c|c|c|c|c|}
\hline \multirow{3}{*}{ City } & \multicolumn{6}{|c|}{ Number of tourists [mln] } & \multirow{2}{*}{\multicolumn{2}{|c|}{$\begin{array}{l}\text { Tourist Function } \\
\text { Index }\end{array}$}} & \multirow{2}{*}{\multicolumn{2}{|c|}{$\begin{array}{c}\text { Tourist/resident } \\
\text { ratio }\end{array}$}} & \multirow{3}{*}{$\begin{array}{c}\begin{array}{c}\text { Inhabit- } \\
\text { ants } \\
{[\mathrm{m} / \mathrm{n}]}\end{array} \\
2018\end{array}$} \\
\hline & \multicolumn{2}{|c|}{ total } & \multicolumn{2}{|c|}{ foreign } & \multicolumn{2}{|c|}{ domestic } & & & & & \\
\hline & 2010 & 2018 & 2010 & 2018 & 2010 & 2018 & 2010 & 2018 & 2010 & 2018 & \\
\hline Budapest & 2.5 & 4.5 & 2.1 & 3.8 & 0.4 & 0.7 & 2.57 & 2.98 & 1.45 & 2.57 & 1.753 \\
\hline Prague & 4.7 & 7.9 & - & 6.7 & - & 1.2 & 7.34 & 7.02 & 3.70 & 6.17 & 1.294 \\
\hline Warsaw & 7.8 & 9.7 & 2.6 & 2.7 & 5.2 & 7.0 & 1.39 & 1.76 & 4.54 & 5.49 & 1.765 \\
\hline
\end{tabular}

Source: Author's own work based on data obtained from statistical yearbooks of cities and countries (CZSO 2018a; CZSO 2018b; HCSO 2018; SOW 2018; SP 2018). 
and electronic publications were used. The following indicators were used: tourist/resident ratio, tourist function index (Defert function). Survey research was performed using a questionnaire for tourists visiting the studied cities - both domestic and foreign tourists. The questionnaire was prepared in the language of each given country and in three other languages: English, German, and Spanish. Data were then collected from June to August 2017. This time period was selected due to its largest influx of tourists and tour groups as well as the largest number of stays confirmed by statistical data. The locations of survey sites were selected based on statistical data on tourist traffic, hotel room occupancy, and expectations based on study visits in selected cities. The sites normally consisted of major tourist attractions and selected accommodations facilities. A total of 550 tourist surveys were completed including 150 in Prague, 150 in Budapest, and 250 in Warsaw. The survey included both quantitative and qualitative questions such as the goal of the visit, visit duration, means of travel, and manner in which the trip had been organized.

\section{Results \\ Tourist profile}

The survey showed similarities and differences in the socio-demographic tourist profiles for the analyzed cities. There were slightly more women than men in the survey $(51 \%)$. The visitors surveyed were mostly foreign tourists (75.5\%). The largest share of domestic tourists were noted for Warsaw (35\%) and Prague (26\%) (Tab. 2). However, national statistical data show a smaller share of domestic tourists in Prague and Budapest in the last year (Tab.1).

The largest age group consisted of tourists 20 to 39 years of age. Both in Prague and Warsaw the highest age group was younger at 15 to 30 years. The share of senior citizens was the smallest - below 5\% (Tab. 2). According to national statistics, the share of senior citizens increased in the visitor total (7\% to $8 \%$ ) in last year. The influx of older foreign visitors increased in Prague and Budapest especially in the summer. The majority of domestic survey respondents fell within the

Table 2. General characteristics of the studied sample (\%)

\begin{tabular}{|c|c|c|c|}
\hline Specification & Budapest & Prague & Warsaw \\
\hline \multicolumn{4}{|l|}{ Gender } \\
\hline Female & 51.0 & 49.5 & 51.5 \\
\hline Male & 49.0 & 50.5 & 48.5 \\
\hline \multicolumn{4}{|l|}{ Age } \\
\hline $15-19$ & 6.5 & 7.5 & 6.5 \\
\hline 20-29 & 35.5 & 34.5 & 38.0 \\
\hline $30-39$ & 32.0 & 32.5 & 24.0 \\
\hline $40-49$ & 18.0 & 14.5 & 16.5 \\
\hline 50-59 & 4.5 & 16.5 & 11.5 \\
\hline$\geq 60$ & 3.5 & 4.5 & 3.5 \\
\hline \multicolumn{4}{|l|}{ Occupation } \\
\hline Employee & 60.0 & 51.3 & 56,5 \\
\hline Student & 29.5 & 39.5 & 32.5 \\
\hline Pensioner & 3.5 & 4.5 & 3.5 \\
\hline Other & 7.0 & 4.7 & 7.5 \\
\hline
\end{tabular}

Source: Based on data from interview. 
age group 15-49. In Warsaw, young groups of tourists tend to dominate, accounting for $42 \%$ of all domestic tourists due to a large number of school trips and visits by relatives and friends. There were significantly more full-time employees (56\%) and students (35\%) among the studied tourists.

International tourists dominated the surveyed sample, where European Union tourists made up of more than half the sample. The main nationalities were German, British, American, Italian, Spanish, and French (Tab. 3). The share of tourists from some countries in the studied cities varied, but most tourists came from Germany and Great Britain. The share of tourists from the United States was highest in Prague and Budapest. Only $1 \%$ of the tourist total (each) in the studied cities originated in Norway and Finland. The number of tourists from CEE countries visiting the studied cities is relatively small in Prague and Warsaw. According to statistical data, the share of Asian and American tourists is highest in Prague (Fig. 1).

The survey showed that the average length of a tourist stay in the studied cities was 2 to 4 days and varied based on tourist age, country of origin, and purpose of visit. The longest stays were reported by persons visiting from the United States, Canada, South Korea, China, and Brazil (more than 5 days). In the case of one- or two-day stays, the most common countries of origin were Great Britain, Ireland, Germany (especially individuals 15 to 39 years old), Czech Republic, Slovakia, Austria, and Romania. Most domestic tourists (83\%) stayed one day in each studied city. According to statistical data, foreign tourists stay the longest in Prague and Budapest - an average of 2.4 days. The shortest average stays were noted for Warsaw (1.7 days) (CZSO 2018b; HCSO 2018; SOW 2018). Statistical data have shown that the length of the average city stay is decreasing over

Table 3. Tourists in the studied sample by region (\%)

\begin{tabular}{|c|c|c|c|}
\hline Country of origin & Budapest & Prague & Warsaw \\
\hline Austria & 6.0 & 1.5 & - \\
\hline Great Britain & 10.0 & 7.0 & 11.5 \\
\hline Germany & 17.0 & 13.0 & 10.0 \\
\hline France & 3.5 & 4.0 & 5.0 \\
\hline Ireland & 1.5 & 2.0 & 2.0 \\
\hline Italy & 8.0 & 4.5 & 4.0 \\
\hline Spain & 4.0 & 5.5 & 5.0 \\
\hline Czech Republic & 1.0 & 26.0 & - \\
\hline Hungary & 12.5 & 3.0 & - \\
\hline Poland & 2.0 & 2.0 & 35.0 \\
\hline Romania & 3.0 & & \\
\hline Slovakia & 2.0 & 1.5 & - \\
\hline Ukraine & 2.5 & 2.0 & 7.0 \\
\hline Russia & 6.0 & 3.0 & 1.5 \\
\hline South Korea & 1.0 & 3.0 & - \\
\hline Canada & 3.5 & 0.5 & 2.5 \\
\hline US & 6.5 & 6.0 & 5.0 \\
\hline Others & 10.0 & 15.5 & 11.5 \\
\hline
\end{tabular}

Source: Based on data from interview. 


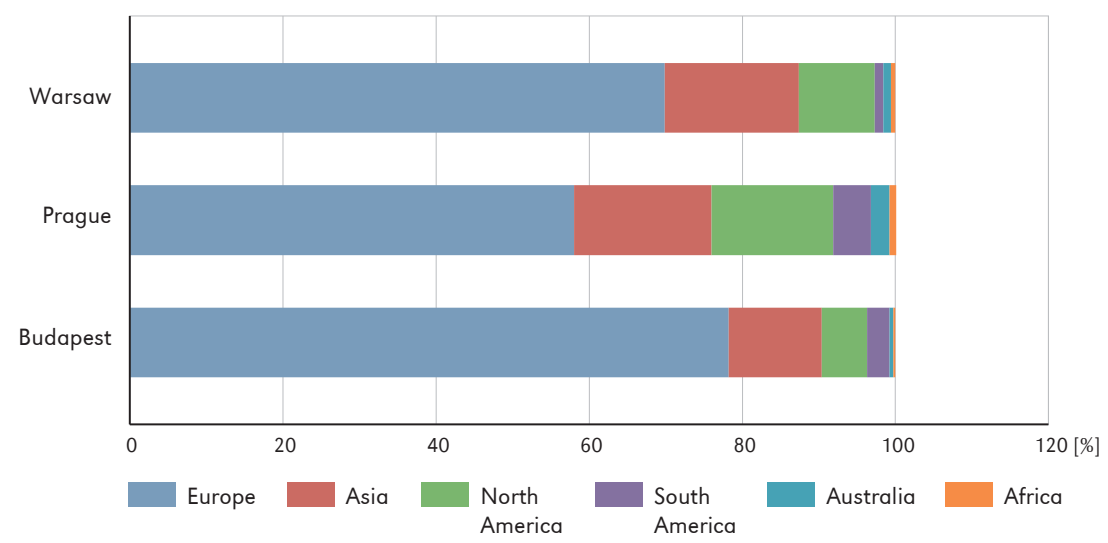

Figure 1. Foreign tourists in the studied cities by region in 2017

Source: Author's own work based on statistical yearbooks (CZSO 2018a; HCSO 2018; SOW 2018; SP 2018), Annual Report... (Prague City Tourism 2018).

time due to the arrival of an increasing number of one-day tourists and tourists merely passing through to other cities.

Self-organized travel was found to be the main form of travel in the studied sample (69\%). Prague and Budapest attract more tourists (82\%) who organize their travel themselves or have it done for them by family members or friends. The surveyed tourists used different sources of information before their trip, with most using the Internet. Their self-organized travel was based on information posted on the websites of the studied cities (89\%), travel web portals (51\%). and social networks (42\%). About 30\% of visitors took advice from friends or relatives who had visited some of these cities before.

Research results showed that visitors in these three cities were not significantly different in terms of transportation choices. The main form of transportation in the studied sample was the airplane (78\%) followed by the car (18\%) and bus (4\%).

\section{Reasons for visiting studied cities}

The surveyed tourists indicated a number of reasons for visiting the studied cities. The most frequent reasons were a desire to pursue cultural tourism, leisure and entertainment (Tab. 4). Tourists were interested in discovering historical sites, architecture, learn about local culture and historical heritage and experience the ambience of the given city. Leisure and entertainment were the second most popular reason for visiting. Other reasons were business and seeing family and friends (Tab. 4).

Each studied age group varied in terms of how it ranked specific reasons for visiting. The main reasons for the younger group (15 to 29 years of age) were discovering unknown places and cultures (58\%), meeting with friends (18\%), participation in entertainment and cultural events (39\%), and education (9\%). The entertainment option was especially important for tourists visiting Prague and Budapest. Tourists 30 to 39 years of age placed emphasis on sightseeing historical sites (50\%), leisure and recreation (35\%), participation in entertainment events (42\%), sports and cultural events (24\%), and business meetings (14\%). The 40 to 59 age group and the 60 and above age group were characterized by the following reasons for visiting: sightseeing historical sites and learning about a city's culture (72\%), leisure (36\%), meetings with friends and family $(27 \%)$, health reasons $(11 \%)$, and sightseeing religious sites. The 20 to 39 age group originating in Great Britain, Germany, France, Italy, and Spain most often cited entertainment, 
recreation, and leisure as the primary reasons for visiting (69\%). This study has made it possible to formulate a relationship between reasons for visiting the studied cities and the age and gender of tourists based on survey data and data from national statistics sources in each of the studied cities (Fig. 2).

Table 4. Main reasons for visiting Budapest, Prague, and Warsaw (\%)

\begin{tabular}{|l|r|r|r|r|r|r|r|}
\hline \multirow{2}{*}{ Reasons for visiting } & \multicolumn{2}{|c|}{ Budapest } & \multicolumn{2}{c|}{ Prague } & \multicolumn{2}{c|}{ Warsaw } \\
\cline { 2 - 7 } & domestic & foreign & domestic & foreign & domestic & foreign \\
\hline Cultural attractions & 53 & 75 & 56 & 72 & 45 & 32 \\
\hline Sightseeing (monuments site) & 62 & 68 & 62 & 80 & 35 & 22 \\
Historical heritage & 30 & 37 & 34 & 56 & 28 & 20 \\
Visit museums, galleries, exhibitions & 23 & 15 & 19 & 13 & 6 & 2 \\
Cultural events & \multicolumn{7}{|l|}{} \\
\hline Leisure and recreations & 22 & 70 & 39 & 75 & 12 & 23 \\
\hline Entertainment (clubbing, party) & 41 & 59 & 6 & 4 & 4 & 5 \\
Leisure (Spa \& wellness, thermal baths) & 1 & 3 & 1 & 1 & 2 & 1 \\
Sports (events) & 7 & 11 & 9 & 12 & 6 & 4 \\
\hline Others & 16 & 9 & 11 & 9 & 9 & 4 \\
\hline Business, conference & 7 & 5 & 2 & 1 & 10 & 7 \\
Shopping & 3 & 2 & 6 & 1 & 5 & 2 \\
VFR & 72 &
\end{tabular}

Source: Based on data from interview.

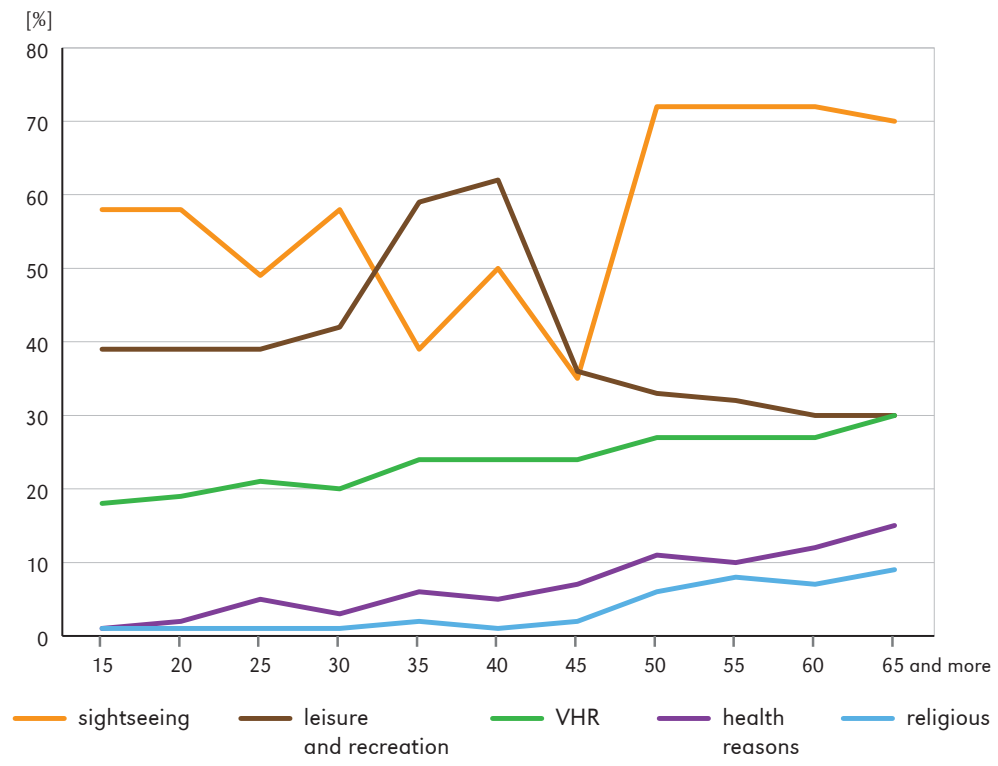

Figure 2. Relationship between tourists' age and reasons for visiting the studied cities Source: Based on data from interview. 


\section{Relationship between tourist profile and tourism development strategy}

Research results show that each examined city assumes in its long-term tourism development policy a significant increase in the number of tourists - and this includes especially foreign tourists - via further expansion of tourism-related facilities as well as expanded tourist offerings and promotional strategies. In the period 2010-2017, the largest increase in the number of tourists was noted for Prague (51\%) and Warsaw (23.1\%). (Tab. 1). In addition, foreign tourists are much more likely to visit Prague and Budapest. The two cities use their cultural heritage and cultural diversity to create a very unique experience for tourists. The share of domestic tourists is larger than the share of foreign tourists in Warsaw (about 70\%). On the other hand, the share of domestic tourists in Prague and Budapest does not exceed 16\%. Warsaw tended to support domestic tourism, while Budapest and Prague became more focused on forms of tourism that appeal to international tourists. One of the main targets of those three cities was to develop conference tourism and business tourism. Especially Prague and Budapest as a popular tourist destination developed recreational tourism and entertainment-oriented tourism. (UMSW 2005; Praha.eu 2010).

The second step is for a city to build a strong brand abroad. Cities use their cultural heritage and cultural diversity to create a very unique experience for most tourists, especially tourists from West Europe. Cities have developed recognizable tourism products such as night entertainment (i.e. Prague by Night, Budapest by Night). These efforts have resulted in a significant increase in the number of tourists. Both Prague and Budapest have begun to promote a local package of city break options. Warsaw is now replicating these forms of urban tourism to encourage more tourists to visit. The promotion and expansion of city break tourism has led to an increase in the number of hotels and flight connections to the studied cities (Tab. 5, Tab. 6). Prague features the largest number of highly-ranked hotels (36.9\%), which favors the growth of MICE tourism. Budapest and Warsaw are also growing their highly-ranked hotel sectors. The development of tourism is aided by expanding airline connections operated by low-cost airlines. Prague Airport is the regional leader in the number of passengers and flight connections. Airports in Warsaw and Budapest compete with Prague in terms of the number of passengers and flight connections.

Current city tourism development strategies (up to the year 2020) often focus on the main principles of sustainable development and local potential to create high quality tourism products that allow a given city to compete. In addition to having similar tourism development strategies, the studied cities are also realizing a variety of projects. Warsaw intends to promote: (1) cultural events (i.e. festivals, educational itineraries such as new trials), (2) increase conference-based and business-based tourism sectors (UMSW 2005). Prague's tourism development program

Table 5. Accommodations in selected countries and cities in 2017

\begin{tabular}{|l|c|c|c|c|c|c|}
\hline \multicolumn{1}{|c|}{ Specification } & $\begin{array}{c}\text { Czech } \\
\text { Republic }\end{array}$ & Prague & Poland & Warsaw & Hungary & Budapest \\
\hline Number of accommodation [units] & 9,168 & 787 & 10,681 & 168 & 3,537 & 643 \\
Number of beds [thousand] & 717 & 90.9 & 769 & 31.0 & 353.2 & 52.4 \\
Hotels & 2,540 & 526 & 2,540 & 111 & 1,059 & 307 \\
Hotels 4 and 5 & 714 & 264 & 694 & 28 & 215 & 95 \\
\hline
\end{tabular}

Source: Based on data obtained from statistical yearbooks of the analyzed countries and cities (CZSO 2018a; HCSO 2018; SOW 2018; SP 2018) and Eurostat 2017. 
Table 6. Main airports in analyzed countries and number of passengers in 2010-2017

\begin{tabular}{|c|c|c|c|c|c|c|}
\hline \multirow{2}{*}{ Country } & \multirow{2}{*}{$\begin{array}{c}\text { Number } \\
\text { of International } \\
\text { Airports }\end{array}$} & \multirow{2}{*}{$\begin{array}{l}\text { Main } \\
\text { Airports }\end{array}$} & \multicolumn{3}{|c|}{ Number of passengers } & \multirow{2}{*}{$\begin{array}{l}\text { Destination/ } \\
\text { carrier }\end{array}$} \\
\hline & & & $\begin{array}{l}2010 \\
{[\mathrm{~m} / \mathrm{n}]}\end{array}$ & $\begin{array}{l}2017 \\
{[\mathrm{~m} / \mathrm{n}]}\end{array}$ & $\begin{array}{c}\text { change } \\
{[\%]}\end{array}$ & \\
\hline $\begin{array}{l}\text { Czech } \\
\text { Republic }\end{array}$ & 5 & $\begin{array}{l}\text { Václav Havel } \\
\text { Airport Prague }\end{array}$ & 11.8 & 13.1 & 11.0 & $\begin{array}{l}160 \text { destina- } \\
\text { tions / } 69 \text { air } \\
\text { carriers }\end{array}$ \\
\hline Hungary & 5 & $\begin{array}{l}\text { Budapest } \\
\text { Ferenc Liszt } \\
\text { International } \\
\text { Airport }\end{array}$ & 8.2 & 11.4 & 39.0 & $\begin{array}{l}125 \text { des- } \\
\text { tinations } \\
\text { to } 45 \text { countries } \\
\text { / } 44 \text { air carriers }\end{array}$ \\
\hline Poland & 14 & $\begin{array}{l}\text { Warsaw } \\
\text { Chopin Airport }\end{array}$ & 9.3 & 12.8 & 37.6 & $\begin{array}{l}119 \text { destina- } \\
\text { tions / } 35 \text { air } \\
\text { carriers }\end{array}$ \\
\hline
\end{tabular}

Source: Based on data obtained from Annual Analyses of the EU Air Transport Market 2016, European Commission 2017, Statistical yearbooks of countries (CZSO 2018a; CZSO 2018b; HCSO 2018; SP 2018).

refocused in 2013 on balancing several different priorities: (1) standard tourism with a special emphasis on domestic tourists, meetingoriented tourism (MICE), film and culinary tourism, slow tourism, (2) cultural events, sports events, and educational events, international in nature (City of Prague 2009; Prague City Tourism 2018). Budapest's main growth strategy is to develop its recreational and health tourism sectors including spa and wellness facilities along with cultural tourism as well as to increase its share of domestic tourists (Hungarian Tourism Agency 2017).

In response to the needs of the tourist, many cities are utilizing advanced technologies to manage tourist traffic and tourist services. Mobile smartphone applications (e.g. Prague.eu, Warsaw Tour) are enabling tourists to discover main city attractions and design customized itineraries. These functions offer a variety of forms of urban tourism - they are globally recognizable and encourage tourists to visit a given city again.

\section{Discussion}

The present study suggests that tourists visiting Prague, Budapest and Warsaw are not statistically different in terms of most demographic variables and some travel patterns. The tourists in the present study are predominantly working individuals and students. The largest studied group consisted of tourists 20 to 49 years old. This age structure is typical for tourists visiting cities, including groups of tourists motivated by culture (Amir et al. 2014; von Rohrscheidt 2016).

Foreign tourists who visit the studied cities usually arrive from Western Europe and Southern Europe. The number of Asian and CEE visitors to the analyzed cities is low. But the share of tourists from China and South Korea has increased in recent years in Prague (7.6\% foreign tourists) and Budapest (4.7\%) (statistical yearbooks - CZSO 2018a; CZSO 2018b; HCSO 2018; SOW 2018; SP 2018). It is clear that tourism management strategies should place more emphasis on the Asian market including China and South Korea and should also refocus on visitors from CEE and North America. The share of tourists from different countries differs in each city due to each city's history and heritage, its urban landscape, geographic location, brand image, and effects of each given city's tourism management efforts. Tourists visiting Berlin and Vienna often visit the Prague and Budapest as a part of the trip program. For this reason, Prague and Budapest receive more foreign tourists than Warsaw. On other hand, Warsaw competes with Kraków (the second tourist center in Poland) in terms of foreign 
tourists. Prague, Budapest and Warsaw also make an effort to remain at the top of MICE tourism rankings (UMSW 2005; Hungarian Tourism Agency 2017; Prague City Tourism 2018).

Capital cities are multifunctional, which attracts a variety of different types of visitors thanks to an array of different attractions. Research results show that cultural and entertainment activities are the main reasons for visiting Prague, Budapest, and Warsaw. Other studies show that the history and heritage and cultural value of these cities are their main attractions. An example can be Vienna, Barcelona, and Melaka (Amir et al. 2014; Dumbrovská \& Fialová 2014; Colomb \& Novy 2017). Mixed-purpose travel is typical of citybreak tourists in search of cultural and entertainment offerings (Dunne et al. 2010). Both Budapest and Prague also welcome a substantial number of business tourists, conference tourists, and shopping-oriented tourists.

Budapest, Prague, and Warsaw exhibit many similarities in the area of urban tourism development. The impact of globalization on the tourism industry has resulted in the recent emergence of homogeneous tourism products (Maitland 2012). Most urban areas imitate projects which have been carried out in other cities such as night entertainment. Stag tourism, hen tourism, and clubbing have become increasingly popular forms of tourism in Prague and Budapest. This type of tourism product attracts tourists mostly from Western Europe, although domestic tourists are now also taking advantage of this form of tourism (Thurnell-Read 2012; Iwanicki et al. 2016). This fact may to some extent affect the demographic profile of tourists visiting the studied cities and their purpose of travel. The age group 20 to 39 years somewhat dominate the population of tourists, especially foreign tourists, visiting the studied cities. This group of tourists tends to be focused on a superficial examination of the cultural heritage of a city via the sightseeing of only main tourist attractions and an affinity for entertainment and the pursuit of the so-called climate of the city (Colomb
\& Novy 2017; Tracz et al. 2019). Research has shown that younger visitors in Budapest and Prague prefer pubs, bars, clubs and discos, while older visitors prefer cultural venues and restaurants (Dumbrovská \& Fialová 2018; Pinke-Sziva et al. 2019). In addition, a large migration of CEE residents to Western Europe for both employment and education purposes has sparked an increase in the number of low-cost airline connections with many cities across Europe. This key factor has increased the number of tourists visiting family and friends.

The short-trip (weekend) market is very important for cities and a great opportunity for cities to expand the tourist season to all seasons of the year. Visitors who go on weekend to Budapest, Prague, and Warsaw are middle class individuals, couples with no children, and young adults. This helps expand cultural, recreational and entertainment options (e.g. Jewish cultural heritage, socialist heritage, new shopping and convention centers, new tourist trails). On the other hand, the observed rapid increase in the number of weekend trips and associated expansion of infrastructure in historic city centers often create conflicts between residents and tourists. Residents most often identify the following issues with increasing tourist volumes: overcrowded city centers, inappropriate tourist behaviors, alcohol abuse, and sex tourism (Deichmann 2002; Pixová \& Sládek 2017).

\section{Conclusions}

Urban tourism in the analyzed cities is a product based on supply and demand focused on cultural heritage and cultural diversity in order to create a very unique experience for tourists. The problem consists of a lack of balance between the number of domestic and foreign tourists in the studied cities.

Prague, Budapest, and Warsaw have been popular weekend destinations (city breaks) for tourists in the last several years The present study has shown that cities compete in terms of urban tourism, including in terms of cultural tourism offerings. Tourists visiting 
Budapest, Prague and Warsaw have a similar socio-demographic profile in terms of gender, age, and employment. The largest age group was that of tourists 20 to 39 years of age. What differentiates the tourists visiting the studied cities is their country of origin. Prague is popular with Germans, the British, Americans and Russians. Warsaw is popular with the British, Germans, Ukraine, French, Italians and Spaniards. Budapest is popular with German, the British, Italians and Russians. The most often cited reasons for travel were the desire to pursue cultural tourism, leisure and entertainment.

These findings suggest that the analyzed cities' marketing efforts should concentrate more on sustainable tourist offerings exploring niche urban tourism forms such as culinary, film, and coffee culture tourism. CEE cities should also promote longer stays by offering tours of surrounding area attractions.

The results of the study may be useful to researchers in the area of tourism and to decision makers working on the formulation of tourism development strategies for cities. The key limitation of this study is the fact that it is based on summer data only.

Editors' note:

Unless otherwise stated, the sources of tables and figures are the authors', on the basis of their own research.

\section{References}

Aguayo E., 2005. Tourism in Central Europe: A comparison of the regions of Poland, Hungary, Czech Republic, Slovakia and Slovenia with other European countries in year 2000. Regional and Sectoral Economic Studies, vol. 5-2, pp. 19-35.

Amir Z., Osman M.M., Bachok S., Ibrachim M., 2014. Understanding tourists' profile and preference of tourists' destination choice: a case study in Melaka world heritage city. Planning Malaysia: Urban Planning and Local Governance, vol. 3, pp. 81-94. https://doi.org/10.21837/pmjournal.v12.i3.133

Ashworth G., Page S.J., 2011. Urban tourism research: Recent progress and current paradoxes. Tourism Management, vol. 32, no. 1, pp.1-15. https://doi.org/10.1016/j.tourman.2010.02.002

Banaszkiewicz M., Grabun N., Owsianowska S., 2017. Tourism in (post)socialist Eastern Europe. Journal of Tourism and Cultural Change, vol. 15, no. 2, pp. 109-121. https://doi.org/10.1080/14766825.2016.1260089

Bellini N., Pasquinelli C. (eds.), 2016. Tourism in the city: Towards an integrative agenda on urban tourism. New York: Springer.

City of Prague, 2009. Programme for the implementation of the Prague strategic plan for the 20092015 Period. Retrieved from http://www.iprpraha.cz/uploads/assets/Realizace_komplet_angl.pdf [25 July 2018].

Colomb C., Novy J. (eds.), 2017. Protest and resistance in the tourist city. London: Routledge. https://doi.org/10.4324/9781315719306

Correia A., Kozak M., Ferradeira J., 2013. From tourist motivations to tourist satisfaction. International Journal of Culture, Tourism and Hospitality Research, vol. 7, no 4, pp. 411-424. https://doi.org/10.1108/IJCTHR-05-2012-0022

CZSO, 2018a. Statistical Yearbook of the Czech Republic. Prague: Czech Statistical Office.

CZSO, 2018b. Statistical Yearbook of Prague. Prague: Czech Statistical Office.

Čuka P., Dorocki S., Rachwał T., 2015. Development of tourism infrastructure in the regions of Central and Eastern Europe [in:] Innovation Vision 2020: From Regional Development Sustainability to Global Economic Growth, May 7-8, 2015, Amsterdam, Netherlands, vol. 25, pp. 402-417.

Deichmann J.I., 2002. International tourism and the sensitivities of central Prague's residents. The Journal of Tourism Studies, vol. 13, no 2, pp. 41-52. 
Dumbrovská V., Fialová D., 2014. Tourist intensity in capital cities in Central Europe: Comparative analysis of tourism in Prague, Vienna and Budapest. Czech Journal of Tourism, vol. 3, no 1, pp. 5-26. https://doi.org/10.2478/cjot-2014-0001

Dumbrovská V., Fialová D., 2018. The city of one hundred souvenir shops: authenticity of souvenirs in Prague. Journal of Tourism and Cultural Change, pp. 1-14. https://doi.org/10.1080/14766825.2019.1606228

Dunne G., Flanga S., Buckley J., 2010. Towards an understanding of international city break travel. International Journal of Tourism Research, vol.12, no. 5, pp. 409-417. https://doi.org/10.1002/jtr.760

Edwards D., Griffin T., Hayllar B., 2008. Urban tourism research: Developing an agenda. Annals of Tourism Research, vol. 35, no. 4, pp. 1032-1052. https://doi.org/10.1016/j.annals.2008.09.002

European Cities Marketing, 2017. European Cities Marketing Benchmarking Report 2017 confirms the resilience of European cities. Retrieved from https://www.europeancitiesmarketing.com/europeancities-marketing-benchmarking-report-2017-confirms-the-resilience-of-european-cities/ [25 June 2018].

EUROSTAT, 2017. http://ec.europa.eu/eurostat/statistics-explained/index.php?title=File:Tourist_accommodation_establishments,_2016.png [25 June 2018].

Hall C.M., Page S.J., 2006. The geography of tourism and recreation: Environment, place and space. 3rd edition, London: Routledge. https://doi.org/10.4324/9780203420249

Harrison D., Sharpley R., 2017. Mass tourism in a small world. Oxfordshire, Wallingford, UK: CABI. https://doi.org/10.1079/9781780648545.0000

HCSO, 2018. Statistical Yearbook of Hungary. Budapest: Hungarian Central Statistical Office.

Hungarian Tourism Agency, 2017. National Tourism Development Strategy 2030: Executive Summary. Retrieved from https://mtu.gov.hu/documents/prod/mtu_strategia_2030-english.pdf

Ibrahimova G.H., 2012. Tourism development challenges in Central and Eastern Europe. Saarbrücken: LAP LAMBERT Academic Publishing.

Iwanicki G., Dłużewska A., Kay M.S., 2016. Assessing the level of popularity of European stag tourism destinations. Quaestiones Geographicae, vol. 35, no. 3, pp. 15-29.

https://doi.org/10.1515/quageo-2016-0023

Kowalczyk A., 2003. Geografia turyzmu. Warszawa: Państwowe Wydawnictwo Naukowe.

Kovacs Z., Wiessner R., Zischner R., 2015. Beyond gentrification: Diversified neighbourhood upgrading in the inner city of Budapest. Geografie, vol. 120, no. 2, pp. 250-273.

Marak J., Wyszkowski J., 2012. The position of countries of Central and Eastern Europe on the international tourism market [in:] K. Widawski, J. Wyszkowski (eds.), Geography of tourism of Central and Eastern Europe, Wrocław: University of Wrocław, pp. 1-17.

Michalko G., 2001. Social and geographical aspects of tourism in Budapest. European Spatial Research and Policy, vol. 8, no. 1, pp. 105-118.

Milano C., 2017. Overtourism and tourismphobia: Global trends and local contexts. Barcelona: Ostelea School of Tourism \& Hospitality. Retrieved from https:/www.researchgate.net/profile/Claudio_Milano3/publication/323174488_Overtourism_and_Tourismphobia_Global_trends_and_local_contexts/ links/5a842fd7a6fdcc6f3eb52e40/Overtourism-and-Tourismphobia-Global-trends-and-local-contexts.pdf [20 August 2019].

Maitland R., 2012. Global change and tourism in national capitals. Current Issues in Tourism, vol.15, no. 1-2, pp.1006-1024. https://doi.org/10.1080/13683500.2011.634890

Nyaupane G.P., Andereck K.L., 2014. Visitors to cultural heritage attractions: An activity-based integrated typology. Tourism Culture \& Communication, vol. 14, no. 1, pp. 17-26. https://doi.org/10.3727/109830414X14038917832824

Pearce D.G., 2001. An integrative framework for urban tourism research. Annals of Tourism Research, vol. 28, no. 4, pp. 155-197. https://doi.org/10.1016/s0160-7383(00)00082-7

Pinke-Sziva I., Smith M., Olt G., Berezvai Z., 2019. Overtourism and the night-time economy: A case study of Budapest. International Journal of Tourism Cities, vol. 5, no. 1, pp. 1-16.

https://doi.org/10.1108/IJTC-04-2018-0028 
Pixová M., Sládek J., 2017. Touristification and awakening civil society in post-socialist Prague [in:] C. Colomb, J. Novy (eds.), Protest and resistance in the tourist city, London: Routledge, pp. 73-89.

Poria Y., Reichel A., Cohen R., 2013. Tourists perceptions of World Heritage Site and its designation. Tourism Management, vol. 35, pp. 272-274. https://doi.org/10.1016/j.tourman.2012.02.011

Prague City Tourism, 2018. Annual Report Prague City Tourism. Retrieved from https://www.praguecitytourism.cz/file/edee/en/annual-reports/19006_vyrocni-zprava-2018_en_a4_verze2_web.pdf [20 June 2019].

Praha.eu, 2010. Hodnocení Programového prohlášení Rady hl. m. Prahy pro volební období 2006 - 2010 - kapitola II. Moderní veřejná správa. Magistrát hl. m. Prahy. Retrieved from: http://www.praha.eu/jnp/ cz/o_meste/magistrat/tiskovy_servis/tiskove_zpravy/hodnoceni_programoveho_prohlaseni_rady_2.html [25 July 2018].

Reisinger Y., 2012. International tourism: Cultures and behavior. London - New York: Routledge.

Richards G., 2018. Cultural tourism: A review of recent research and trends. Journal of Hospitality and Tourism Management, vol. 36, pp. 12-21. https://doi.org/10.1016/j.jhtm.2018.03.005

Simpson F., 1999. Tourist impact in the historic centre of Prague: Resident and visitor perceptions of the historic built environment. Geographical Journal, vol. 165, no. 2, pp. 173-183. https://doi.org/10.2307/3060415

SOW, 2018. Statistical Yearbook of Warsaw. Warsaw: Statistical Office in Warsaw.

SP, 2018. Statistical Yearbook of the Republic of Poland 2018. Warsaw: Statistics Poland.

Thurnell-Read T., 2012. Tourism, place and space: British stag tourism in Poland. Annals of Tourism Research, vol. 39, no. 2, pp. 801-819. https://doi.org/10.1016/j.annals.2011.09.009

Tracz M., Bajgier-Kowalska M., Wójtowicz B., 2019. Przemiany w sferze usług turystycznych Krakowa i ich wpływ na percepcję turystyki przez mieszkańców. Prace Komisji Geografii Przemysłu Polskiego Towarzystwa Geograficznego, vol. 33, no 1, pp. 164-177.

Trew J., Cockerell N., 2002. The European market for UK city breaks. Insights, vol. 14, no 58, pp. 85-111.

UMSW, 2005. Strategia rozwoju miasta stołecznego Warszawy do 2020 roku. Warszawa: Urząd m.st. Warszawy, retrieved from http://strategia.um.warszawa.pl/sites/default/files/strategia_rozwoju.pdf [2 August 2018].

UNWTO, 2016. City Tourism Network: Action Plan 2016/2017. World Tourism Organization, retrieved from http://cf.cdn.unwto.org/sites/all/files/pdf/unwto_action_plan_2017.pdf [20 July 2018].

UNWTO, 2017. Tourism Highlights: 2017 Edition. Madrid: World Tourism Organization, retrieved from https://www.e-unwto.org/doi/pdf/10.18111/9789284419029 [20 July 2018].

UNWTO, 2018a. Tourism Highlights: 2018 Edition. Madrid: World Tourism Organization, retrieved from https://www.e-unwto.org/doi/pdf/10.18111/9789284419876 [20 June 2019].

UNWTO, 2018b. Tourism and Culture Synergies. Madrid: World Tourism Organization, retrieved from https://doi.org/10.18111/9789284418978

Widawski K., Wyszkowski J. (eds.), 2012. Geography of tourism of Central and Eastern Europe. Wrocław: University of Wrocław.

Vagner J., 2007. Tourism development in the Visegrad Four countries in the period of the EU access. Acta Universitatis Carolinae, Geographica, no 1-2, pp. 75-89.

von Rohrscheidt A.M., 2016. Turystyka kulturowa. Fenomen, potencjat, perspektywy. Poznań: Wydawnictwo KulTour.pl.

Zduniak A., 2017. Eventy jako ponowoczesna forma uczestnictwa w życiu społecznym. Roczniki Nauk Społecznych, vol. 38, no 1, pp. 207-234. 